\title{
R. N. MACEDONIA AND THE CFSP OF THE EUROPEAN UNION: ACHIEVEMENTS AND CHALLENGES
}

\begin{abstract}
Three determinants shape the role and influence of the EU as a global-regional actor in peace and security: capacity (institutional, material, human and operational, as well as financial) to undertake missions; willingness to devote resources to security and defence purposes, mainly driven by member states' priorities; and acceptance (internal and external) of the EU as a leading actor in peace and security. The institutional security and defence framework of the EU has undergone many reforms in the past three decades. The beginnings of this process have been established by the Treaty of Maastricht (1992) that has established the EU Common Foreign and Security Policy (CFSP). By the Stabilization and Association Agreement entering into force, R.N. Macedonia has officially confirmed its determination for moving closer to the CFSP goals. Therefore, the paper analyses the process that R.N. Macedonia is implementing regarding this issue, as well as it faced challenges.
\end{abstract}

Keywords: EU, CFSP, SAP, R.N. MACEDONIA

\section{Introduction}

Within the institutional and legal framework of the European Union (EU), the Common Foreign and Security Policy (CFSP) is being introduced with the 1992 European Union Treaty, also known as the Maastricht Treaty. The CFSP established aim strengthening of the common values, European identity and independence in promoting peace and security in Europe and the world, as well as to safeguard the security of the EU itself and its member states (Георгиева, 2010). Moreover, the Treaty of Maastricht notes that"... the Common Foreign Security Policy includes all matters related to the security of the Union, including the final creation of a common defence policy ..." (The Treaty of Maastricht, 1992). Actually, the CFSP has been developed as a major coordination mechanism for the member states' external policies, which provides a joint response to the situations and challenges about which there is an interest for a common response. So, the CFSP is a result of the common interest of all EU member states that define a common attitude towards various foreign policy issues, through their institutional mechanisms. 
These common attitudes are often offered for an adoption to the candidate countries for membership, such as the R.N. Macedonia, as well as to the potential candidates. According to Article 11 of the Maastricht Treaty, the main objectives of the CFSP are as follows: (Hauser, 2006):

- safeguarding of the common values, fundamental interests and independence of the Union in accordance with the UN Charter principles;

- strengthening of the Union security, as well as of its Member States;

- preserving peace and strengthening international security, in accordance with the United Nations Charter principles as well as the principles of the Helsinki Final Act and the objectives of the Paris Charter;

- promoting international cooperation;

- developing and consolidating democracy and the rule of law, as well as respecting of human rights and fundamental freedoms.

By the Stabilization and Association Agreement entering into force, the R.N. Macedonia begins the harmonization process of its policies in the security and defence sphere related to the CFSP objectives. Starting from 2006, through the annual reports of the European Commission about the R.N. Macedonia progress, the progress about this issue is being measured within the chapter No.31. In this hand, the annual reports confirm that the R.N. Macedonia has made a significant progress regarding its approximation to the CFSPgoalsin the past 12 years.

\section{The Treaty of Lisbon (2009) and the Common Foreign and Security Policy}

By the Lisbon Treaty (2009), the CFSP implementation is defined in more detail. Actually, the Lisbon Treaty additionally strengthens the position of the High Representative for the CFSP, otherwise introduced by the Treaty of Amsterdam in 1997. In this context, the High Representative is simultaneously becoming the Vice President of the European Commission, as well as the Director of the European External Action Service. This two-dimensional function aim is unifying of the activities of the two Union institutions: the Council of Ministers and the European Commission, regarding to the foreign policy sphere issues (Георгиева, 2015). Actually, by the Treaty of Lisbon, the High Representative for the CFSP receives authorization for establishing peacekeeping, conflict prevention and strengthening of international security missions (The Treaty of Lisbon: 2009). He can as well propose using of national resources and instruments of the Union, when required. Therefore, the CFSP is still linked to the intergovernmental process, and any change in it, is a matter of the unanimity principle i.e. a matter of consensus. 


\section{A harmonization framework with the EU Common Foreign and Security Policy}

The R.N. Macedonia harmonization framework with the EU CFSP is composed of several normative and strategic documents, such as: the Constitution, the Defence Law, the National Concept on Security and Defence, the Strategy for Integration of the R.N. Macedonia in the EU, the Strategy for National Security and the White Defence Paper. All these documents confirm the strategic determination of our country for EU membership and hence, its approximation and harmonization with CFSP.

On the other hand, the Stabilization and Association Process (SAP) countries have been called to join the EU's CFSP on the 2003 Thessaloniki Agenda, as part of the political dialogue with the EU. In summary, according to the text of the Agenda, whenever the necessity is considered: "The EU will urge the SAP states to join the Union's demarches, declarations and common positions regarding to the CFSP" (The Thessaloniki Agenda: 2003).

The R.N. Macedonia is the first country that has signed the Stabilization and Association Agreement and the first country where the SAA has come into force. The SAA was signed on 9 April 2001 in Luxembourg and, after its ratification by all signatories, entered into force on 1 April 2004. By the Agreement signing, the R.N. Macedonia committed itself-gradual alignment with the EU's foreign policy at political level, and with its entering into force, it has become a legal obligation for our country.

The arising obligations from the political dialogue are regulated on the basis of Article 7 of the Agreement. Actually, this Article specifies the R.N. Macedonia obligations related to the CFSP, i.e. that the political dialogue purpose is specifically aimed at (Stabilization and Association Agreement, 2001):

- increased convergence of the Parties positions on international issues, especially on those issues that will be probably have a significant impact on the parties;

- regional cooperation and promotion of good neighbourly relations; and

- common views on security and stability in Europe, including the areas covered by the EU's CFSP.

The parties undertake a developing of mutual political dialogue, which will monitor and promote an approximation between the EU and the R.N. Macedonia, as well as will contribute in establishing closer relations of solidarity and new forms of cooperation. An Article 9 stresses the manner in which the political dialogue will be realized, primarily within the Stabilization and Association Council framework. At the request by the parties, it is also envisaged that the political dialogue should take place through meet- 
ings of senior officials of the R.N. Macedonia and the Chairman of the Council of the EU and the Commission, as well as through diplomatic channels between the parties, relevant contacts in third countries, as well as within the United Nations, OSCE and other international forums.

\section{The EU Annual Reports on the Progress of the R.N.Macedonia - Chapter No. 31}

After achieving the status of a candidate country for membership in December 2005, starting from 2006, the R.N. Macedonia receives an annual EU report on its progress in where its achievements are evaluated and recommendations are given regarding the implementation of the Copenhagen criteria. The progress of the R.N. Macedonia (as well as other Western Balkan countries) is measured through the adopted decisions, the adopted legislation and the implemented measures. In addition, the legislation or measures that are under preparation or are waiting to be adopted, are not taken into consideration.

The R.N. Macedonia contribution to the CFSP and the European security is assessed within the chapter No.31 of the report, which annually receives the state from the EU about the progress made in the field of the CFSP.

The negotiating chapter No. 31, i.e. the EU's Common Foreign and Security Policy is generally treated as an easy negotiating chapter, as it contains a relatively modest number of legally binding issues that need to be adopted. Actually, the international treaties are in focus regarding to this issue. Within this chapter, it is expected that future EU members should adopt and comply with the Union political decisions, measures, statements and positions, more closely.

Actually, the candidate countries are required for gradually complying with EU statements, as well as for applying sanctions and restrictive measures when and where they will be required. This approach goal is creating a safe European environment and developing the capacities of the Western Balkans countries (including the R.N. Macedonia) for their active contributeon to the European security. The decisions and measures as well, are adopted at the level of the EU Council of Foreign Affairs and the European Council and are mandatory for the Member States. Actually, these decisions are result of common interests and attitudes that Member States share in foreign policy and security area and imply the need for unanimous decision-making, with the possibility of so-called constructive restraint - instrument introduced by the Amsterdam Treaty, 1997.

The R.N. Macedonia is currently not in a position to participate in the decision-making process with the EU Member States, and hence its focus in this area is aimed at accepting and adapting to the adopted decisions. How- 
ever, until the moment of joining the EU, it is expected to progressively join to the Union declarations, as well as developing appropriate institutional capacities in order to effectively perception of this area dynamics. By the end of the completion of EU membership negotiations, the candidate country should achieve full (100\%) compliance with the CFSP. The situation regarding this issue in R.N. Macedonia for the period from 2010 to 2017, is as follows:

\begin{tabular}{|c|c|c|c|c|c|c|}
\hline \multicolumn{7}{|c|}{$\begin{array}{l}\text { Accepted and Harmonized EU declarations and Council decisions related } \\
\text { to the CFSP in } \%\end{array}$} \\
\hline 2010 & 2011 & 2012 & 2013 & 2014 & 2015 & 2016 \\
\hline $100 \%$ & $99 \%$ & $100 \%$ & $94 \%$ & $73 \%$ & $68 \%$ & $73 \%$ \\
\hline
\end{tabular}

The R.N. Macedonia actively accompanies the implementation of the EU Council decisions, restrictive measures (sanctions) against states, entities, organizations, individuals, during this period. These measures are essentially aimed at maintaining international peace and security, respecting of human rights and fundamental freedoms, the democracy development as well as the rule of law. Restrictive measures are one of the mechanisms for preventing the terrorist organizations financing, controlling weapons, and preventing the spread of weapons of mass destruction as well as for the prevention of a range of other criminal activities.

It should be noted that regarding to this issue, in 2014 R.N. Macedonia abstained from joining the EU Council decision for restrictive measures regarding to the activities for violation or endangering the territorial integrity, sovereignty and independence of Ukraine as well as restrictive measures directed against certain persons, entities and bodies related to the situation in Ukraine.

The R.N. Macedonia has also refrained from joining of the EU Council Decision 2011/173/CFSP on restrictive measures in relation to the situation in Bosnia and Hercegovina. On the other hand, the past period has been very intense in the context of joining the EU Council decisions about providing the establishment of restrictive measures towards third countries related to the situation in the Arab world. As a result, in March 2011, a new Law on Implementation of International Restrictive Measures has been adopted, that should provide more effective implementation of UN sanctions and autonomous restrictive measures of the EU.

The EU's CFSP harmonization is also perceived in terms of common values, as the R.N. Macedonia as a candidate for membership should show that cherishes and shares the same values with the EU member states as well as that shares the same strategic commitments with the EU, especially in respecting of International law and human rights. The issue of harmonization in the field of the CFSP is also perceived from the solidarity principle aspect, whereby it is expected a manifestation of Macedonian intention to be part of 
the EU positions. It implies certain disclaimers, as well as the challenges sharing.

Apart from the joining of the EU Council of Foreign Affairs declarations aspect, at a multilateral level, the EU closely follows the activities of the R.N. Macedonia, especially in the context of numerous international organizations (UN, OSCE, Council of Europe, etc.), within which, the Union acts with a single position whenever it is possible.

The European Union expects joining both, the candidate and candidate countries, when a common position will be achieved. Therefore, it is expected that R.N. Macedonia will support the EU positions on a multilateral level, by the starting of negotiations for EU membership. Quite often, these positions and attitudes are criticized by certain states about disregarding the International law principles, jeopardizing security, etc., which in a value proposition initiates certain requirements which future EU member states must accept in a greater extent (on e.g. condemnation of the death penalty, massive violation of human rights, etc.).

An important segment, which is also followed within Chapter 31, is the acceptance and adaptation of the EU's institutional framework in the field of the Common Security and Defence Policy as an integral part of the CFSP. In this regard, it is important that the National foreign policy and security-strategic framework should be harmonized with the EU, as well as that foreign policy and security challenges should be defined from the EU perceived aspect.

The strengthening of the Macedonia state institutions capacities and the readiness for providing as much support as possible in accordance with their own capacities in the EU military and civilian missions is also an important contribution to EU policy. In accordance to the R.N. Macedonia Integration Strategy in EU (2004), the state will endeavour to provide the operational capacity of civilian and military funds about the realization and participation in missions outside its territory, whose only goals, in accordance with the UN Charter principles, will be (Strategy: 2004):

- Peace keeping;

- Conflict prevention;

- Strengthening international security.

In this regard, the R.N. Macedonia creates a necessary framework for its direct and active participation in EU-led operations in the civil and military crisis management, besides the declarative commitments for respecting the Union's declarations and attitudes related to this issue.

In accordance with its National Security and Defence Concept as well as its Strategic Defence Review, starting from 2003, Macedonia conducted a comprehensive reform of the security and defence system. The Macedonian 
participation in the EU military operation EUFOR Althea (since 2006), also provides additional credibility to Macedonia's efforts for actively contribution to the European Security and Defence Policy development as well as to the European security in general.

\section{Conclusion}

It can be concluded that the Republic of Macedonia in the past 12year period has made significant steps regarding the approximation to the goals of the CFSP, from today's perspective. Among other issues, confirmations about it are as follows:

- the established database of common positions and statements with the EU;

- the established working group about the promotion of coordination between the competent authorities regarding to the process of the restrictive measures implementation;

- the adopted Law on International Restrictive Measures on 23.3.2011;

- the establishment of a Coordinative Body for Monitoring the International Restrictive Measures implementation (2012) as well as the establishment of a Register of International Restrictive Measures, within the Ministry of Foreign Affairs;

- participation in the Wassenaar Arrangement (starting from 2012);

- the establishment of a certified computer unit for accessing to the EU network for electronic exchange of classified information from the CFSP;

- signed bilateral agreements for exchange and mutual protection of classified information with several European countries.

On the other hand, it still remains as an open question the fact that Macedonia's signed bilateral agreement with the United States on the surrender of certain individuals (American citizens) to the International Criminal Court (ICC). Regarding to this issue, the EU notes that the state has ratified the Rome Statute in 2002, but it also stressed that the signed bilateral agreement with the United States is not in accordance with its (EU) position and therefore it is highlighting a necessity of Macedonia adjusting to its position. 


\section{References}

Ayrault, J.M. and Steinmeier, F.W. (2016). A strong Europe in a world of uncertainties. Available at: https: www.voltairenet.org/IMG/pdf/DocumentUE-2.pdf [Посетено на 18 февруари 2019]

Brentherton, CH., Volger, J. (2006). EU as a global actor. London: Routledge.

Cormick, Mc. (2009). The European Union and the Global Governance. London: Routledge.

Европска комисија, Извеитаи за Р. Македонија (2010-2016). Брисел. Достапни на: https://www.sobranie.mk/dokumenti-rm-eu-cbb3490c-fe7d-4750-82f4-67c619c46a6a.nspx. [Посетено на 20 март 2019]

EU Common Foreign and Security Policy. (1992). Available at: https://eeas.europa.eu/headquarters/headquarters-homepage/420/common-foreignand-security-policy-cfsp_en [Посетено на 15 февруари 2019]

Георгиева, А. (2010). Европска безбедност. Скопје: Филозофски факултет.

Георгиева, А. (2015). Заедничка безбедносна и одбранбена политика на Европската унија. Скопје: Филозофски факултет.

Гоцевски, Т., Бакрески, О., Славевски, С. (2007). Европската унија низ призмата на европската безбедност. Скопје: Филозофски факултет.

Аазаров, А. (2005). Европската унија, состојби и перспективи. Скопје: Култура.

Macedonia and the region towards EU and NATO: needs, experiences and lessons learned: regional conference (2006). Skopje: Friedrich Ebert Stiftung.

Michelle, C. (2010). European Union politics. Oxford: Oxford University Press.

Нацев, 3., Ѓорески, И. (2013). Управуване со системот за одбрана на Република Македонија. Скопје: Филозофски факултет.

Peterson, J., Sjursen, H. (1998). A Common foreign policy for Europe. London: Routledge.

Smith, K. (2009). European Union Foreign Policy in changing world. Cambridge: Blackwell Pub.

Спогодба за стабилизациија и асоичијациија меѓу Република Македонија и Европската заедница и нејзините држави членки. (2001). Службен весник на Република Македонија, 13 април, 2001. Достапно на: http://www.sep.gov.mk/data/file/SSA/SSA(1).pdf [Посетено на 22 март 2019]

Treaty on European Union, Maastricht, 7 February, 1992. Достапно на: https://www.cvce.eu/content/publication/2002/4/9/2c2f2b85-14bb-4488-9ded-13f3cd04de05/publishable_en.pdf [Посетено на 24 февруари 2019] 
Treaty of Amsterdam, 2 October, 1997. Достапно на: http://www.europarl.europa.eu/topics/treaty/pdf/amst-en.pdf [Посетено на 25 февруари 2019]

Treaty of Lisbon, 13 December, 2007. Достапно на: http://en.euabc.com/uplo$\mathrm{ad} /$ books/lisbon-treaty-3edition.pdf [Посетено на 26 февруари 2019]

Wessels, W., Bopp, F. (2008). The CFSP after the Lisbon Treaty: Constitutional break-through or challenges ahead. No.235, 1-43. 